\title{
Kapitał społeczny i ludzki jako niematerialny zasób rozwoju lokalnego w świetle badań ankietowych mieszkańców wsi województwa pomorskiego
}

\section{Social and human capital as an intangible resource for local development in view of the questionnaire study of rural inhabitants in Pomorskie Province}

\author{
Maciej TARKOWSKI \\ Uniwersytet Gdański \\ Katedra Geografii Rozwoju Regionalnego \\ ul. Bażyńskiego 4, 80-309 Gdańsk \\ maciej.tarkowski@ug.edu.pl
}

\begin{abstract}
Zarys treści: W artykule przedstawiono terytorialne zróżnicowanie kapitału ludzkiego i społecznego na przykładzie obszarów wiejskich województwa pomorskiego ogółem, w podziale na gminy podmiejskie i pozostałe wiejskie oraz w podziale na regiony historyczne. Kapitał ludzki rozumiany jest jako zestaw wiedzy, umiejętności i kompetencji służących aktywności ekonomicznej. Kapitał społeczny to umiejętności współpracy międzyludzkiej w obrębie grup i organizacji, w celu osiągnięcia wspólnych interesów. Oba rodzaje kapitału stanowią istotny niematerialny zasób rozwoju lokalnego. W artykule skupiono się na przybliżeniu aspektów, które z uwagi na trudność pomiaru są pomijane w większości badań wykorzystujących dane wtórne. W tym celu wykorzystano dane pierwotne pochodzące z badania ankietowego na próbie 7,1 tys. osób (w tym 2,3 tys. mieszkańców wsi). Analizie poddano zagadnienia: wartości w życiu, zaufania do innych osób i instytucji, identyfikacji i związków z miejscem zamieszkania oraz postaw wobec pracy. Na podstawie uzyskanych wyników sformułowano trzy grupy wniosków: (1) zróżnicowanie badanych cech w układzie miasto-wieś nie było tak znaczne, jak pokazują najczęściej stosowane wskaźniki aktywności społecznej i przedsiębiorczości; (2) podmiejskie położenie, poza zjawiskami wprost zależnymi od korzyści aglomeracji, nie miało większego wpływu na badane cechy; (3) nie stwierdzono wyraźnych różnic w przekroju regionów historycznych, choć w jednym zaobserwowano pewne odmienności.
\end{abstract}

Słowa kluczowe: kapitał ludzki, kapitał społeczny, obszary wiejskie, województwo pomorskie.

\section{Wstęp}

Różnorodność i zmienność warunków oraz czynników rozwoju społeczno-gospodarczego (Walukiewicz 2007), a także nieostrość tego pojęcia (Krzysztofek i Szczepański 2005) skutkują wielością teorii próbujących w całościowy sposób odpowiedzieć na pytanie o źródła zamożności albo biedy regionów (Gorzelak 2003; Sagan 2007; Grosse 2002). Pojęcie rozwoju analizowane jest w różnych skalach przestrzennych. Jak zauważa J.J. Parysek (1997), od koń- 
ca lat 70. XX w. w Europie Zachodniej, w odpowiedzi na kryzys polityki regionalnej, a szerzej kryzys gospodarczy świata zachodniego, popularność zaczęło zdobywać pojęcie rozwoju lokalnego. W fundamentalnych dla tamtego okresu pracach W.J. Coffey i M. Polese (1984, 1985) podkreślali odrębność tak rozumianego rozwoju względem rozwoju regionalnego, akcentując znaczenie czynników endogenicznych, w szczególności lokalnej przedsiębiorczości. Jej rozwój miał być wspierany poprzez zapewnienie wsparcia finansowego, informacji, a także aktywizacji życia społecznego. Na pozaekonomiczne aspekty rozwoju lokalnego zwracali uwagę G. Becattini i in. (2003). Podsumowując dorobek „florenckiej szkoły” badań lokalnej przedsiębiorczości, podkreślali oni rolę społecznych, kulturowych i instytucjonalnych podstaw rozwoju lokalnego. Transformacja ustrojowa spowodowała wzrost zainteresowania problematyką rozwoju lokalnego w Polsce. R. Brol (1998) podkreślił, że rozwój lokalny zachodzi w warunkach zharmonizowanego i systematycznego działania lokalnej wspólnoty, zmierzającego do kreowania nowych i wzmocnienia istniejących walorów użytkowych, poprawy warunków prowadzenia działalności gospodarczej, kształtowania ładu ekologicznego i społecznego. J.J. Parysek (1997) potwierdził rolę samorządu lokalnego w sterowaniu rozwojem lokalnym, który służyć ma urzeczywistnieniu interesu ogólnospołecznego i indywidulnego, poprzez podnoszenie zdolności konkurencyjnej miejscowej gospodarki oraz ukształtowanie odpowiedniego środowiska i warunków życia mieszkańców.

Różnorodność lokalnych warunków i czynników rozwoju uniemożliwia wskazanie ich uniwersalnego zestawu, który decydowałby o sukcesie albo porażce danej społeczności. W tym zakresie formułowane są bardzo różne odpowiedzi, w tym m.in. na gruncie teorii kapitału. Niezależnie od różnic znaczeniowych pojęcia kapitału (Marchewka 2000), w najbardziej ogólny sposób wyróżnić można trzy jego rodzaje: rzeczowy lub finansowy, ludzki i społeczny. Pojęcie kapitału rzeczowego i finansowego stanowi fundament nowoczesnej myśli ekonomicznej, ukształtowanej w XVIII w. Naukowy pogląd o roli kapitału ludzkiego jako czynnika rozwoju społeczno-gospodarczego ewoluował przez cały XX w. Natomiast debata na temat znaczenia kapitału społecznego została zintensyfikowana dopiero pod jego koniec (Janc 2009). Wydaje się, że taka chronologia badań była następstwem ewolucji znaczenia poszczególnych warunków i czynników rozwoju. Jej przyspieszenie nastąpiło w toku globalizacji i wynikającej z niej coraz silniejszej międzynarodowej konkurencji. Jak zauważa M. E. Porter (2000), przewagę konkurencyjną kształtuje zdolność dodania nowej wartości w łańcuchu produkcji. Mniejszą rolę ma więc kapitał rzeczowy czy finansowy, a zdecydowanie większą ludzki i społeczny, które umożliwiają łączenie czynników wytwórczych w unikatowy sposób. Syntezą rozważań na temat roli kapitału w rozwoju społeczno-gospodarczym, uwzględniającym przestrzenne zróżnicowanie jego składowych, jest pojęcie kapitału terytorialnego (Zaucha i in. 2015).

Problematyka kapitału społecznego i ludzkiego jest obecna w geograficznych badaniach wsi, choć niekoniecznie przyjmuje pespektywę teorii kapitału. Wśród tradycyjnych zagadnień badawczych geografii wsi bliskie omawianej tematyce są problemy ludnościowe, rozwoju lokalnego i do pewnego stopnia infrastrukturalne. Zagadnienia nowe - kontrasty społeczne w przestrzeni wiejskiej, polityka i współrządzenie wsią, społeczne zróżnicowanie i codzienność życia wiejskiego - niemal w całości wpisują się w rozważania nad kapitałem społecznym i ludzkim (Wójcik 2013). Oba rodzaje kapitału stanowią też fundamentalne czynniki kształtowania wiejskich obszarów sukcesu gospodarczego (Bański 2008; Czapiewski 2006, 2010), a ich deficyty, szczególnie w zakresie kapitału ludzkiego, są ważnym powodem uznania obszarów za problemowe (Bański 1999). 
Dyskusja nad rolą kapitału ludzkiego i społecznego, jako zasobu niezbędnego w rozwoju lokalnym, stała się przesłanką do opracowania niniejszego artykułu. Jego celem jest uzupełnienie wiedzy na temat kształtowania się obu kapitałów w społecznościach wiejskich Polski na początku drugiej dekady XXI w. o kwestię postaw, które są fundamentem dla kompetencji współtworzących kapitał ludzki i społeczny. Zakres przedmiotowy rozważań wyznaczają definicje obu rodzajów kapitału oraz pojęcie rozwoju lokalnego. Kapitał ludzki rozumiany jest jako zestaw wiedzy, umiejętności i kompetencji ucieleśnionych w człowieku i powiązanych z jego ekonomiczną aktywnością (OECD 1998, za: Janc 2009). Kapitał społeczny to umiejętności współpracy międzyludzkiej w obrębie grup i organizacji, w celu osiągnięcia wspólnych interesów, wynikające z zaufania, istnienia norm oraz sieci i organizacji społecznych (Coleman 1998, za: Janc 2009). Rozwój koncepcji kapitału społecznego doprowadził do wyodrębnienia jego dwóch podstawowych typów. Pierwszy z nich - kapitał wiążący - kształtuje się w toku regularnych interakcji, wzajemnego respektowania zobowiązań, co powoduje powstanie wzajemnego zaufania. Cechą tego rodzaju kapitału są więc silne powiązania międzyludzkie i wysokie zaufanie osobiste. Jeżeli zaufanie to potwierdza się w kolejnych interakcjach, to zostaje one rozszerzone również na kontakty potencjalne. W ten sposób rodzi się drugi rodzaj kapitału społecznego - pomostowy. Cechują go luźne powiązania, ale wysoki poziom zaufania uogólnionego (Działek 2011b). Obie kategorie, choć teoretyczne rozdzielne, w praktyce współwystępują - postawy typowe dla każdego z rodzajów kapitału społecznego, choć w różnym natężeniu, cechują większość ludzi.

Rozwój lokalny - kolejne pojęcie będące przedmiotem niniejszego opracowania - rozumiany jest jako proces kumulujący pozytywne konsekwencje zmian przebiegających według sekwencji opisanej przez J.J. Paryska (1997). Przewiduje ona rozwój lokalnie zakorzenionej przedsiębiorczości, która łącząc specyficzne, miejscowe zasoby, wiedzę i technologię z jej odpowiednikami transferowanymi z zewnątrz, prowadzi do doskonalenia działalności gospodarczej, poprawy pozycji konkurencyjnej lokalnych przedsiębiorstw pozwalającej na ich ekspansję na rynkach ponadlokalnych. Efekty mnożnikowe tego procesu stają się podstawą indywidualnego dobrobytu mieszkańców, jak i całej lokalnej wspólnoty.

Zakres przestrzenny opracowania ogranicza się do obszaru województwa pomorskiego. Analiza ogniskuje się na obszarach wiejskich, choć w celach porównawczych uwzględniono także poziom obu kapitałów w miastach. Obszary wiejskie przenalizowano jako całość, a także przyglądając się bliżej obszarom podmiejskim. Pod uwagę wzięto również historycznie ukształtowane zróżnicowanie przestrzenne województwa pomorskiego. Zasadniczy zakres czasowy ogranicza się do 2014 r., w którym wykonano badanie kwestionariuszowe.

\section{Terytorialne zróżnicowanie kapitału społecznego i ludzkiego w Polsce - dotychczasowe ustalenia}

Analizy terytorialnego zróżnicowania kapitału społecznego i ludzkiego natrafiają na fundamentalną barierę dostępności adekwatnych danych agregowanych do jednostek lokalnych. Badania próbujące przedstawić te zagadnienia w sposób całościowy i oddać ich zróżnicowanie w skali całej Polski (Czyżewski i in. 2001; Działek 2011a; Herbst 2007; Janc 
2009; Wendt 2007; Zaucha i in. 2015) właśnie z tego powodu są w znacznej mierze ograniczone do danych udostępnianych w systemie statystyki publicznej. Dane te, o ile pozwalają na względnie szeroką analizę zmienności kapitału ludzkiego, o tyle w odniesieniu do kapitału społecznego są jedynie częściowo zadowalające. Nie pozwalają również wprost wnioskować o stanie kapitału ludzkiego i społecznego na wsi, gdyż analizy dokonane zostały w układzie województw lub powiatów. Wyniki wskazują na istotne zróżnicowanie obu rodzajów kapitału w układzie centra-peryferie. Wyższe poziomy odnotowane zostały w miastach na prawach powiatu, a niższe na pozostałych obszarach. Biorąc po uwagę rodzaj i terytorialne zróżnicowanie czynników kształtujących poziom obu kapitałów (Janc 2009), w tym uwarunkowanych korzyściami aglomeracji, można z dużą dozą prawdopodobieństwa stwierdzić, że poziom kapitału ludzkiego i społecznego na terenach wiejskich, mierzony wskaźnikami pochodzącymi z systemu statystyki publicznej ${ }^{1}$, jest wyraźnie niższy niż w miastach. Do takiego wniosku uprawniają analizy zróżnicowania wybranych składników kapitału ludzkiego na obszarach wiejskich całej Polski dokonane w układzie gmin (Heffner 2012). Wyraźnie korzystniejsza sytuacja, szczególnie w zakresie demograficznych fundamentów kapitału ludzkiego, cechowała obszary podmiejskie.

Omówione wnioski sformułowano, przyjmując modernizacyjną koncepcję rozwoju, której zasadniczą wadą jest założenie istnienia jednego uniwersalnego modelu przemian społeczno-gospodarczych. Takie podejście umniejsza znaczenie lokalnych uwarunkowań rozwoju (Domański 2004). Równocześnie podejmowane były próby określenia odmienności tych uwarunkowań na obszarach wiejskich, w szczególności w odniesieniu do kapitału społecznego, gdyż w tym zakresie obserwuje się głębsze deficyty na polskiej wsi (Fedyszak-Radziejowska 2005). Fundamentalnym problemem jest niski poziom zaufania do innych osób, choć należy podkreślić, że nie jest to jedynie problem wsi (Czapiński i in. 2015). Analiza pozostałych składowych kapitału ludzkiego, takich jak uczestnictwo organizacyjne, współdziałanie, informacja i komunikacja, inkluzja społeczna oraz poczucie podmiotowości również prowadzi do wniosku o niskim poziomie kapitału społecznego na wsi (Halamska 2008). Analiza B. Fedyszak-Radziejowskiej (2014) z jednej strony wskazuje na odmienność kapitału społecznego na wsi w stosunku do miast, z drugiej stwierdza, że pozytywne zmiany, jakie miały miejsce po akcesji Polski do UE, zostały zatrzymane.

Zagadnienie kapitału społecznego analizowane było również w odniesieniu do pojedynczych województw (Frykowski i Starosta 2005; Kotarski 2013) lub jednostek lokalnych. Szczególnie te ostatnie opracowania poruszają interesujące kwestie, które trudno objąć w większej skali. Poruszono zagadnienia m.in. współpracy sąsiedzkiej (Łabędzki 2011), partycypacji obywatelskiej (Jażdżewska i Frykowski 2006) czy akceptacji norm społecznych (Mularska 2006). Analizy prowadzone były przy zastosowaniu różnych metod i dotyczyły odmiennych wymiarów kapitału społecznego. Wyniki wskazują na jego dość istotne deficyty. Ciekawe wnioski wypłynęły również z doświadczeń tworzenia w Polsce lokalnych grup działania, finansowanych z funduszy europejskich (Psyk-Piotrowska i in. 2013). Pokazują one stosunkowo wysoki, jak dla obszarów wiejskich, po-

${ }^{1}$ W odniesieniu do kapitału ludzkiego są to wskaźniki: poziomu wykształcenia ludności/radnych, obciążenia demograficznego, salda migracji, nadumieralności mężczyzn, poziomu czytelnictwa, zamożności społeczności lokalnych, przedsiębiorczości ludności. W przypadku kapitału społecznego stosuje się najczęściej następujące wskaźniki: liczba fundacji, stowarzyszeń i organizacji społecznych, liczba imprez kulturalnych i zespołów artystycznych, członkostwo w klubach sportowych, zespołach artystycznych i kołach zainteresowań, frekwencja wyborcza. 
ziom kapitału społecznego, w dużej części warunkowany wysokim poziomem kapitału ludzkiego członków. Jednocześnie zauważono, analizując różne jego wymiary, istotną niespójność. Członkowie lokalnych grup działania, zapewne jako zdeklarowani społecznicy, wykazywali przywiązanie do norm i wartości. Jednocześnie zaobserwowano trudność w nawiązywaniu współpracy ponad granicami środowisk najbliższych uczestnikom. Dała o sobie znać bariera w postaci ograniczonego zaufania do osób spoza najbliższego kręgu, czyli deficyt kapitału pomostowego. To cecha typowa dla mieszkańców Polski - nie tylko obszarów wiejskich.

\section{Założenia, metoda i zagadnienia badawcze}

Biorąc pod uwagę dotychczasowe ustalenia w zakresie terytorialnego zróżnicowania kapitału społecznego i ludzkiego, niniejszy artykuł stanowi próbę chociaż częściowego wypełnienia deficytu wiedzy, powstałego na styku badań ogólnopolskich oraz regionalnych i lokalnych. Badania zróżnicowania obu kapitałów w skali kraju, choć dostarczają istotnych informacji, to opierając się na dostępnych danych statystycznych, pomijają kwestie trudno mierzalne, a istotne. Chodzi o systemy wartości i postawy ludzi istotne dla wykształcenia kompetencji warunkujących poziom kapitału ludzkiego i społecznego. Jak zauważa D. Piróg (2015), rozważania na temat rozwoju, także lokalnego, coraz częściej odwołują się do pojęcia profesjonalizmu, w analizach którego stopniowo odchodzi się od stosowania kategorii kwalifikacji, zastępując je pojęciami wiedzy i umiejętności podmiotu - czyli właśnie kompetencji. W niniejszym opracowaniu przyjęto pogłębione, triadowe ujęcie kompetencji, na które składają się trzy sfery: motywów i cech podmiotów, ról społecznych i koncepcji samego siebie oraz wiedzy i umiejętności (Bird 1995, za: Piróg 2015). Choć takie podejście stosuje się najczęściej w analizach cech kapitału ludzkiego, to wydaje się, że z powodzeniem może być stosowane w odniesieniu do kapitału społecznego. Analizę elementów składających się na systemy wartości i postaw mieszkańców województwa pomorskiego umożliwiły wyniki badania ankietowego wykonanego na zlecenie Instytutu Badań nad Gospodarką Rynkową przez Pracownię Badań Społecznych, w dniach 19.04-27.05.2013 r. na losowej próbie 7,1 tys. mieszkańców w wieku powyżej 15 lat. Z tego na wsi przeprowadzono 2,3 tys. wywiadów ${ }^{2}$. Zastosowano metodę bezpośrednich wywiadów kwestionariuszowych w miejscu zamieszkania respondentów. Próba została wylosowana z rejestru adresów gospodarstw domowych, prowadzonych przez Główny Urząd Statystyczny. Gospodarstwa domowe dobierane były metodą random-route, polegającą na poszukiwaniu adresów, poruszając się w ściśle określony sposób, poczynając od wylosowanego punktu startowego. Następnie pod wytypowanym według powyższej reguły adresem losowano respondenta (Raport techniczny... 2013). Wielkość próby, jak i przyjęta metoda doboru respondentów umożliwiły analizę wyników w trzech przekrojach terytorialnych: miasto-wieś, gminy podmiejskie - pozostałe gminy wiejskie, regiony historyczne (ryc. 1).

${ }^{2}$ Wyniki badania ankietowego omawiane w niniejszym opracowaniu uzyskano w toku wykonywania projektu pt. „Wzorcowy System Regionalny Monitoringu Jakości Usług Publicznych i Jakości Życia”, współfinansowanego ze środków Unii Europejskiej w ramach Europejskiego Funduszu Społecznego (Priorytet V POKL 2007-2013 Dobre rządzenie, Działanie 5.2 Wzmocnienie potencjału administracji samorządowe). Więcej informacji na stronie projektu: www.monitoring.ibngr.pl. 


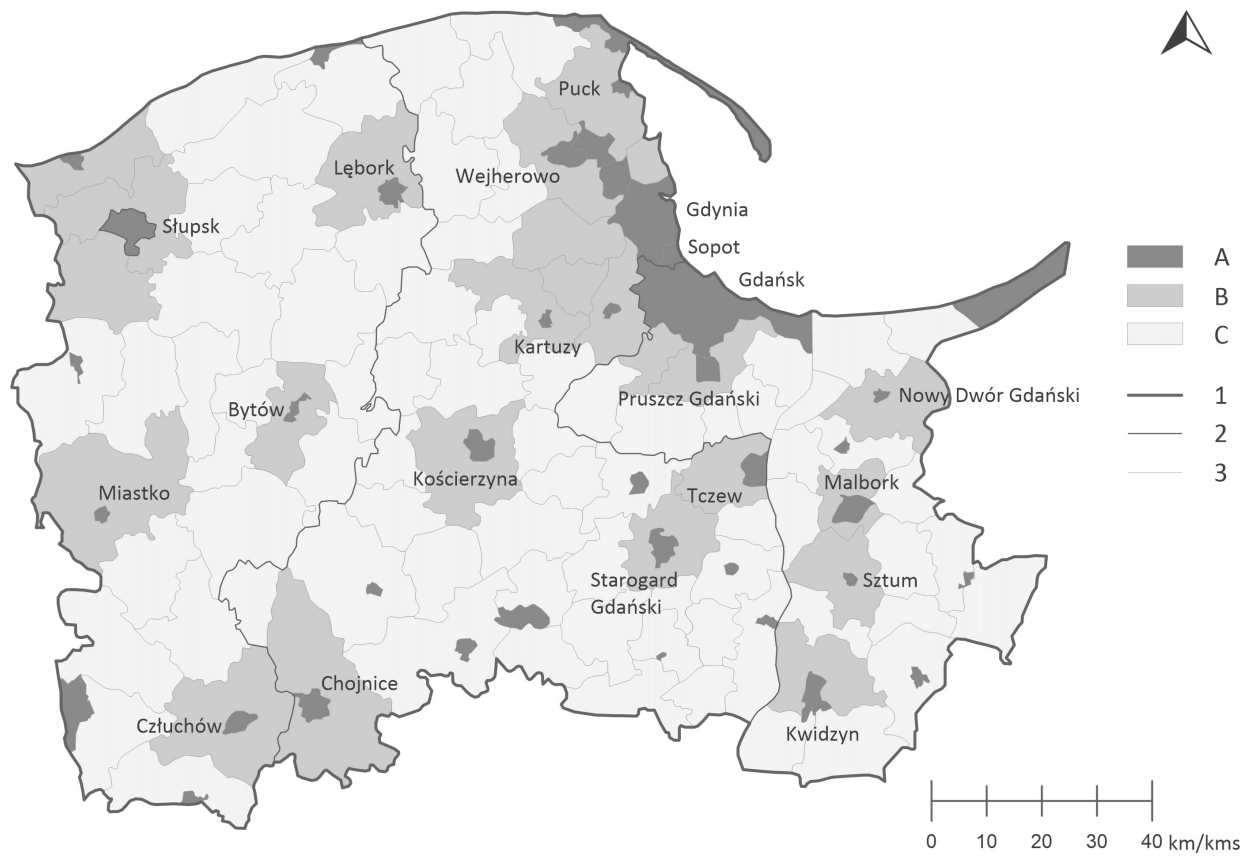

Ryc. 1. Zakres przestrzenny analizy - województwo pomorskie w podziale na: A - miasta, B - podmiejskie gminy wiejskie, C - pozostałe gminy wiejskie, 1 - granica województwa, 2 - granice regionów historycznych, 3 - granice gmin.

Źródło: opracowanie własne.

Spatial scope of the analysis - Pomorskie Province by: A - Cities/towns, B - Suburban rural communes, C-Other rural communes, 1 - Boundary of the province area, 2 -Boundaries of historical regions, 3 -Boundaries of local communes areas.

Source: author's own elaboration.

Przyjęte przekroje terytorialne posłużyły analizie trzech zagadnień badawczych. Po pierwsze, skupiono się na analizie wyników badań ankietowych w kontekście różnic wartości najczęściej stosowanych wskaźników kapitału ludzkiego (poziom przedsiębiorczości) i społecznego (poziom nasycenia organizacjami pozarządowymi) w układzie miasto-wieś (Czyżewski i in. 2001; Działek 2011a; Janc 2009; Wendt 2007; Zaucha i in. 2015). Po drugie, sprawdzono, czy szczególny charakter gmin podmiejskich (Bański 2010; Wójcik 2010) znajduje odzwierciedlenie w odmiennych niż w pozostałych obszarach wiejskich wartościach analizowanych cech. Po trzecie, zweryfikowano, w jakim stopniu historyczne uwarunkowania rozwoju (Działek 2011a) terytorialnie różnicują poziom analizowanych cech.

Analizę wyżej wymienionych zagadnień przeprowadzono w oparciu o odpowiedzi na cztery kwestie poruszane w ankiecie. Pierwszą kwestią były wartości leżące u podstaw szczęśliwego życia. Stanowią one fundament, na którym budowany jest zarówno kapitał ludzki, jak i społeczny. Przywiązanie do wartości takich jak praca, uczciwość czy wykształcenie są istotne w kontekście kształtowania kapitału ludzkiego. Z kolei dla formowania się kapitału społecznego ważna jest ranga przypisywana małżeństwu, dzieciom, uczciwości, życzliwości i szacunkowi otoczenia oraz posiadaniu przyjaciół. Drugą kwestią było zaufanie jako podstawa kapitału społecznego. Zbadano nie tylko jego poziom, ale także w jakim stopniu dotyczy najbliższych osób (kapitał społeczny wiążący) oraz czy obejmuje dalsze 
kręgi (kapitał społeczny pomostowy). Trzecim zagadnieniem był poziom identyfikacji i siła związków z miejscem zamieszkania. Związek ten wydaje się być obustronnie istotny - przywiązanie do miejsca zamieszkania może być katalizatorem procesu wzmacniania kapitału społecznego. Jednocześnie wysoki poziom tegoż kapitału powinien sprzyjać zakorzenieniu mieszkańców i całej społeczności. Zgodnie z przytoczoną wcześniej koncepcją rozwoju lokalnego, wysoki poziom spójności i aktywności społecznej sprzyja miejscowej przedsiębiorczości, która jest głównym motorem tego rozwoju. Czwartą kwestią, istotną dla kształtowania kapitału ludzkiego, była postawa ankietowanych wobec pracy, która warunkuje praktyczne wykorzystanie wiedzy i umiejętności nabytych w toku kształcenia oraz predyspozycje osobiste i doświadczenie życiowe, w tym zawodowe. Efektywność tego połączenia kształtuje produktywność pracy, a co za tym idzie decyduje o pozycji konkurencyjnej przedsiębiorstw i opartemu na niej dobrobytowi materialnemu mieszkańców.

\section{Zróżnicowanie wybranych cech kapitału społecznego i ludzkiego w układzie miasto-wieś}

Nieliczne wskaźniki opisujące ilościowo poziom kapitału społecznego i ludzkiego wskazują na znaczne dysproporcje w układzie miasto-wieś. W 2013 r. najczęściej stosowany wskaźnik poziomu kapitału społecznego - liczba fundacji, stowarzyszeń i organizacji społecznych na 1000 mieszkańców - wynosił w miastach województwa pomorskiego 3,47, podczas gdy na wsi 2,56. W miastach było ich więc o $1 / 3$ więcej. W przypadku podstawowego wskaźnika poziomu kapitału ludzkiego - liczby osób fizycznych prowadzących działalność gospodarczą na 1000 mieszkańców - wartości kształtowały się na poziomie 96 w miastach i 66 na wsi. W stosunku do poziomu notowanego na wsi w miastach liczba tych podmiotów była o 45\% wyższa. Powstaje pytanie, na ile tak znaczne dysproporcje są efektem różnic w poziomie obu kapitałów, a na ile wynikają ze zdyskontowania korzyści aglomeracji i centralnego charakteru miast względem obsługiwanych obszarów wiejskich. Analiza wyników badania ankietowego nie wykazała tak znacznych dysproporcji badanych cech. Hierarchia warunków szczęśliwego życia wśród mieszkańców wsi była zbliżona do odpowiedzi uzyskanych w miastach (ryc. 2). Największa dysproporcja dotyczyła bardzo ważnej cechy dla kształtowania obu kapitałów - uczciwości. Była ona wyraźnie częściej wskazywana na wsi. Przewaga miast dotyczyła znaczenia zdrowia - aspektu ważnego w pierwszej kolejności dla budowania kapitału ludzkiego. Na wsi częściej wskazywano pieniądze, jako warunek szczęśliwego życia, choć trudno to jednoznacznie interpretować z punktu widzenia wpływu na poziom kapitału społecznego i ludzkiego.

Również na pytanie o to, czy warto ufać innym ludziom - czyli o fundament kapitału społecznego - mieszkańcy wsi nieco częściej odpowiadali pozytywnie. Za taką odpowiedzią, podobnie jak w mieście, kryje się jednak przede wszystkim kapitał wiążący. Wysokim zaufaniem obdarza się przede wszystkim członków własnej rodziny, znajomych, ewentualnie prominentnych członków lokalnej społeczności. Ustalenia te są zgodne z wynikami innych badań (Pysk-Piotrowska i in. 2013). Atutem wsi w zakresie wzmacniania kapitału społecznego może być wysokie zaufanie do sołtysów. Ich miejscy odpowiednicy - radni dzielnicowi - nie cieszą się tak wysokim jego poziomem. W świetle dostępnych badań jest to jednak atut w dużej mierze potencjalny, biorąc pod uwagę stosunkowo małe zainteresowanie mieszkańców kształtem funduszu sołeckiego (Ptak 2015). 


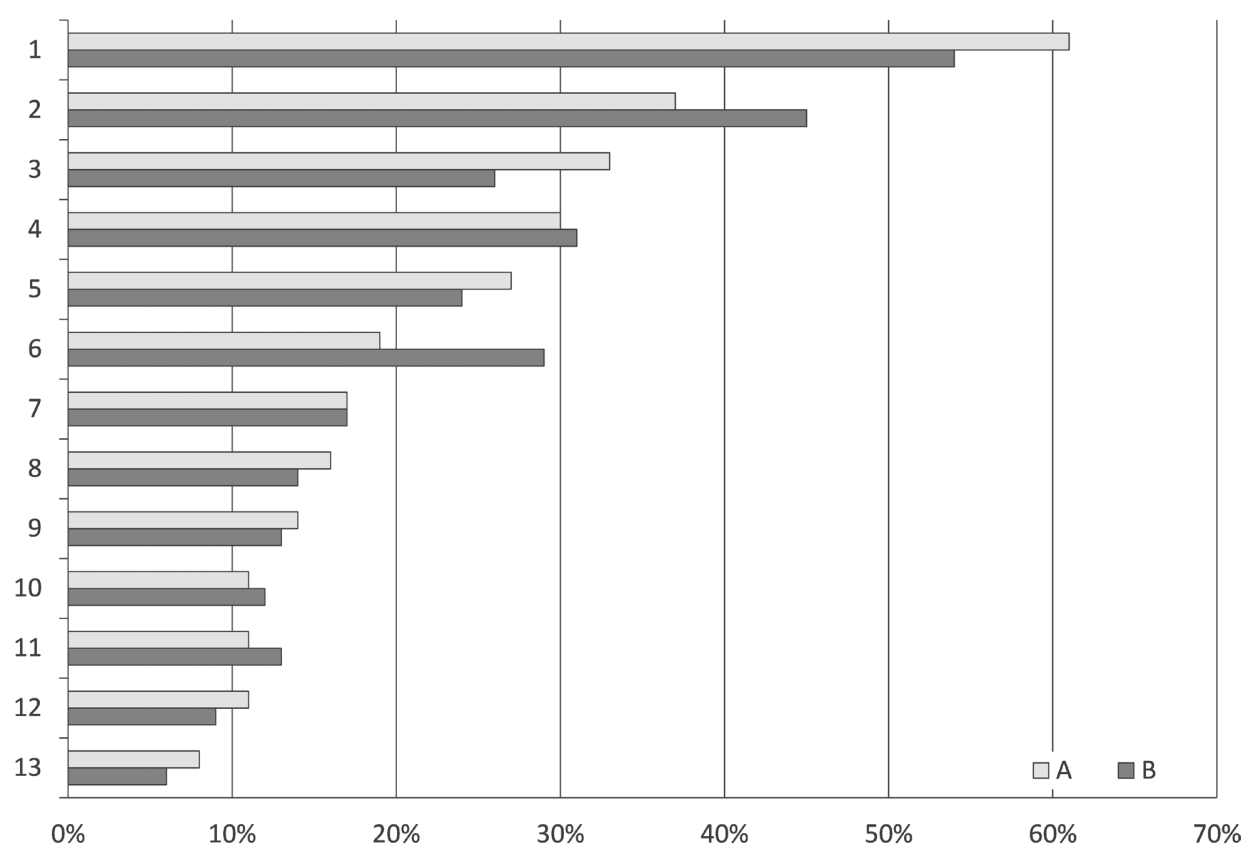

Ryc. 2. Warunki szczęśliwego życia w opinii mieszkańców województwa pomorskiego w 2013 r. A - miasto, B - wieś, 1 - zdrowie, 2 - pieniądze, 3 - udane małżeństwo, 4 -dzieci, 5 - praca, 6 - uczciwość, 7 - opatrzność, Bóg, 8 -życzliwość i szacunek otoczenia, 9 - pogoda ducha, 10 - przyjaciele, 11 - wykształcenie, 12 - silny charakter, 13 - wolność, swoboda.

Źródło: opracowanie własne na podstawie wyników badania ankietowego.

Prerequisites of a happy life according to the inhabitants of Pomorskie Province in 2013. A - Urban areas, B-Rural areas, 1 - Health, 2 - Money, 3 - Successful marriage, 4 - Children, 5 - Work, 6- Honesty, 7 - Providence, God, 8 - Kindness and respect of other people, 9 - Serenity, 10 - Friends, 11 - Education, 12 - Sound character, 13 - Freedom.

Source: author's own study based on questionnaire survey results.

Zagadnienie identyfikacji i związków z miejscem zamieszkania przeanalizowano na podstawie odpowiedzi udzielonych na cztery pytania. Wyłaniający się z nich obraz zróżnicowań w układzie miasto-wieś nie jest jednoznaczny. O ile poczucie związków z okolicą miejsca zamieszkania cechowało się podobnym poziomem, o tyle zadowolenie z tego miejsca było wyższe wśród mieszkańców miast. Wytłumaczyć to można w znacznej mierze korzyściami aglomeracji, zapewniającej lepsze warunki życia. Z drugiej strony to mieszkańcy wsi mieli wyraźnie większe poczucie zaangażowania i współdecydowania o sprawach okolicy, choć podkreślić należy wysoki odsetek niemających opinii w tych sprawach, a także znaczną polaryzację odpowiedzi.

Analizując postawy wobec pracy, należy zaznaczyć, że mieszkańcy wsi gorzej oceniali poziom satysfakcji z pracy. Wynika to z ograniczonych rozmiarów niemetropolitalnych rynków pracy, a także słabszej pozycji przetargowej pracowników względem pracodawców, czego świadomość mieli także respondenci. Analiza postaw oparta została na odpowiedziach na pytanie o przyczyny satysfakcji z pracy. Biorąc odpowiedzi ogółem wszystkich respondentów z województwa pomorskiego do najważniejszych zaliczono powody wynikające z ekonomicznej funkcji pracy - wysokość wynagrodzenia i pewność zatrudnienia. Na drugim biegunie znalazł się elastyczny czas pracy oraz korzyści pozafinansowe (np. służ- 
bowy samochód, telefon, pakiet medyczny). Respondenci mieszkający na wsi wskazali na podobną hierarchię wartości, choć zaistniały pewne różnice w stosunku do odpowiedzi formułowanych przez mieszkańców miast (ryc. 3.). Nieco większą wagę przykładali oni do elastycznego czasu pracy, wysokości wynagrodzenia, a przede wszystkim do korzyści pozafinansowych. Trochę mniej istotna była pewność zatrudnienia oraz kwestie, takie jak wykonywanie pracy, którą się lubi oraz dobra atmosfera w zespole.

Przeprowadzona analiza wybranych wskaźników wykazała, że różnice w każdym z analizowanych aspektów okazały się wyraźnie mniejsze niż można by się tego spodziewać, biorąc pod uwagę wartości podstawowych wskaźników przedsiębiorczości i aktywności społecznej. Okazało się, że w niektórych aspektach korzystniejszą sytuacją cechują się obszary wiejskie. Różnice w poziomie przedsiębiorczości i aktywności społecznej w ograniczonym stopniu wydają się zatem wynikać z odmienności w systemach wartości i postawach mieszkańców.

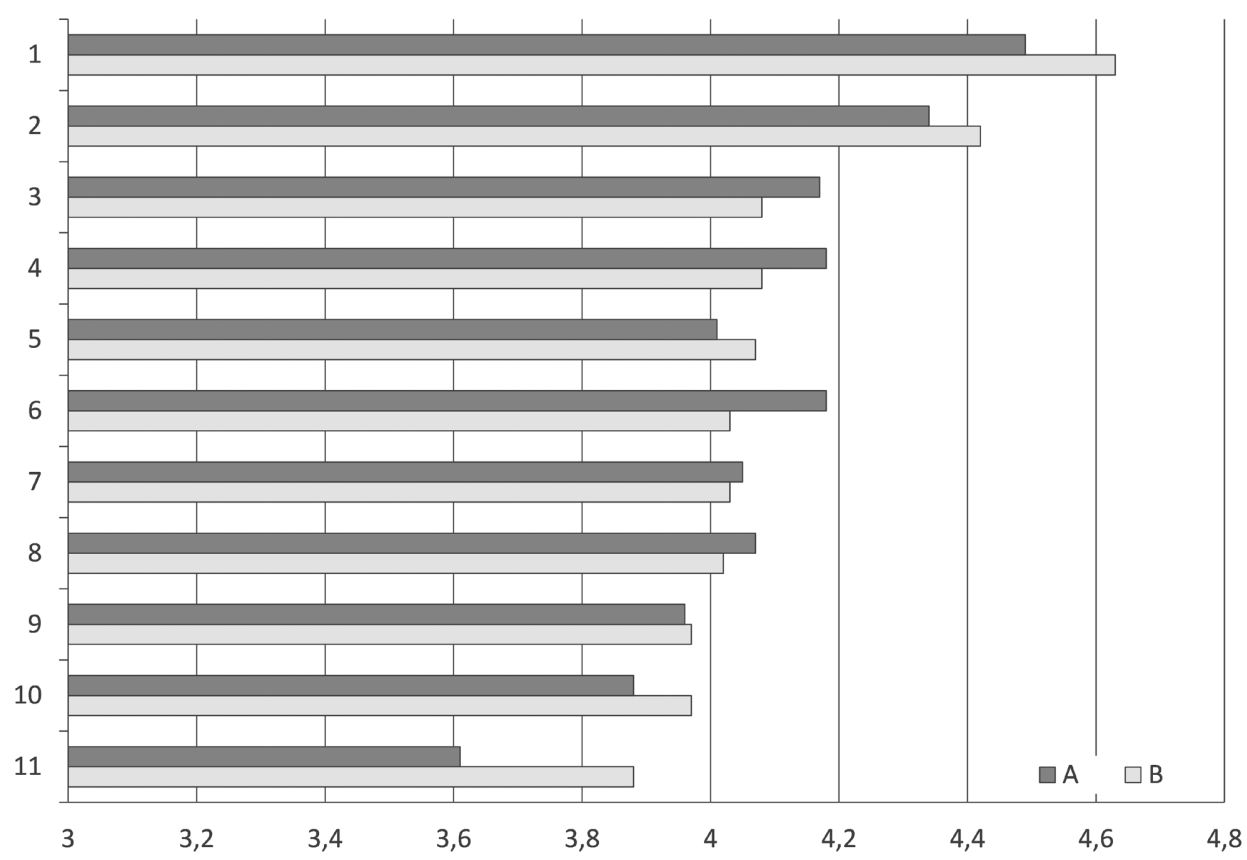

Ryc. 3. Czynniki satysfakcji z pracy (średnia na skali $1-5$, gdzie 1 = nieważna, 5 = bardzo ważna) w opinii mieszkańców województwa pomorskiego w 2013 r.

A - miasto, B - wieś, 1 - właściwe wynagrodzenie, 2 - dodatki motywacyjne do wynagrodzenia, 3 - pewność zatrudnienia, 4 - dobra atmosfera w zespole, 5 - możliwość wzięcia urlopu w dogodnym terminie 6 - wykonanie pracy, którą się lubi, 7 - możliwość awansu, 8 - łatwość dotarcia do miejsca pracy, 9 - możliwość podejmowania samodzielnych decyzji 10 - elastyczny czas pracy, 11 - służbowy samochód, telefon, pakiet medyczny, inne korzyści pozafinansowe.

Źródło: opracowanie własne na podstawie wyników badania ankietowego.

Factors of job satisfaction according to the inhabitants of Pomorskie Province in 2013

A - Urban areas, B - Rural areas, 1 - Appropriate remuneration, 2 - Other financial incentives, 3 - Employment security, 4 - Team spirit, 5 - Ability to take leave at a convenient time 6-Doing work that one likes, 7 -Promotion opportunities, 8 - Easy commute, 9 - Ability to make decisions independently, 10 - Flexible working time arrangements, 11 - Company car, mobile phone, private health insurance, other non-financial benefits. Source: author's own study based on questionnaire survey results. 


\section{Zróżnicowanie wybranych cech kapitału społecznego i ludzkiego w układzie wieś podmiejska - pozostała wieś}

Choć wieś podmiejska, w tym w szczególności metropolitalna, różni się istotnie pod wieloma względami od wsi położonych poza bezpośrednim oddziaływaniem miast, to różnice w zakresie oceny wartości leżących u podstaw szczęśliwego życia nie są duże. Odnotowano trzy różnice istotne dla kształtowania kapitału społecznego i ludzkiego. Respondenci zamieszkujący wsie podmiejskie wyraźnie większą wagę przykładali do udanego małżeństwa, co może przekładać się na poziom kapitału wiążącego. Z kolei mieszkańcy pozostałych wsi wyraźnie większą wagę przykładali do wartości takich jak praca oraz wykształcenie, istotnych dla kształtowania kapitału ludzkiego.

Mimo intensywności chaotycznej suburbanizacji i jej kosztów społecznych (Kowalewski i in. 2014) nie zaobserwowano istotnych różnic w poziomie i strukturze zaufania w przekroju gmin podmiejskich i pozostałych wiejskich.

Spośród pytań charakteryzujących poziom identyfikacji i związków z miejscem zamieszkania wyraźnie zróżnicowane okazały się odpowiedzi dotyczące zadowolenia. Mieszkańcy gmin podmiejskich wyrażali zdecydowanie lepsze opinie niż zamieszkujący pozostałe gminy wiejskie.

Pomiędzy respondentami mieszkającymi w gminach podmiejskich i pozostałych gminach wiejskich zarysowały się również pewne różnice w postawach wobec pracy. Wydaje się, że ich przyczyną jest odmienny stan lokalnych rynków pracy. Gminy podmiejskie stanowią integralną część rynków pracy kształtowanych przez sąsiednie miasta stwarzające więcej możliwości zarówno pracodawcom, jak i pracownikom. W ten sposób wytłumaczyć można wyraźnie wyższy odsetek niezadowolonych z pracy w gminach wiejskich oddalonych od miast. Zamieszkujący gminy podmiejskie nie tylko byli z niej bardziej zadowoleni, ale także podkreślali znaczenie cech pracy, które umożliwiają rozwój zawodowy.

Różnice w poziomie wybranych wskaźników pomiędzy gminami podmiejskimi a pozostałymi wiejskimi nie okazały się znaczne. Wyraźniejsze były jedynie w aspektach powiązanych z korzyściami aglomeracji - zadowoleniem z miejsca zamieszkania i niektórymi oczekiwaniami wobec pracy zawodowej.

\section{Zróżnicowanie wybranych cech kapitału społecznego i ludzkiego w układzie regionów historycznych}

Przez terytorium współczesnego województwa pomorskiego przebiegały w przeszłości trwałe granice polityczno-administracyjne. Przyjmując założenie, że poziom kapitału społecznego to efekt długotrwałych procesów, należy się spodziewać, że powinien on być zróżnicowany w układzie regionów historycznych. Abstrahując od historycznej zmienności bytów politycznych, których terytoria graniczyły ze sobą na obszarze współczesnego województwa pomorskiego (Knieć i in. 2013), podzielono go na trzy regiony o umownych nazwach (Zachodni, Środkowy, Wschodni). Pierwszy z nich to wschodnia część historycznego Pomorza Zachodniego, które przed II wojną światową stanowiło część Niemiec. Drugi - Pomorze Gdańskie, zamieszkałe przez dwie silne mniejszości etniczne - Kaszubów i Kociewiaków, w okresie międzywojennym stanowiło fragment terytorium Rzeczpospolitej Polskiej. Trzeci obszar - obejmuje Powiśle Warmińskie, stanowiące przed 
II wojną światową część Prus Wschodnich oraz część Żuław i obszar Wysoczyzny Gdańskiej, wchodzące w skład terytorium Wolnego Miasta Gdańska. Mimo bogatej historii tych obszarów, to konsekwencje II wojny światowej, w postaci niemal całkowitej wymiany ludności w regionie Zachodnim i Wschodnim, wydają się mieć najdalej idące konsekwencje dla terytorialnego zróżnicowania kapitału ludzkiego i społecznego. Podejście takie przyjął również J. Działek (2011a). Jedną z historycznych konsekwencji mających fundamentalne znaczenie dla rozwoju, a następnie kryzysu obszarów wiejskich w obu tych regionach, była duża rola państwowych gospodarstw rolnych, których likwidacja w toku transformacji ustrojowej, doprowadziła do powstania rozległych obszarów strukturalnego bezrobocia o skutkach odczuwalnych do chwili obecnej. Przyjęty podział w znacznej mierze odpowiada współczesnej typologii obszarów wiejskich na badanym obszarze (Bański 2014).

Analiza wyników badania ankietowego wskazuje na zróżnicowanie wybranych cech w przekroju regionów historycznych, choć nie są to różnice głębokie i powszechne. W zakresie warunków szczęśliwego życia do pewnego stopnia odmienną hierarchię wartości zaobserwowano w regionie Zachodnim. Respondenci z tego obszaru wyraźnie rzadziej podkreślali znaczenie zdrowia i posiadania dzieci. Jednocześnie częściej niż pozostali respondenci wskazywali na opatrzność lub Boga, życzliwość i szacunek otoczenia, pogodę ducha i silny charakter. Co ciekawe, udane małżeństwo, dzieci, Bóg nie były wartościami częściej wskazywanymi w regionie Środkowym, zamieszkałym przez społeczności Kaszubów i Kociewiaków. Najwyższa w Polsce stopa przyrostu naturalnego notowana w kaszubskich gminach wiejskich najczęściej tłumaczona jest właśnie przywiązaniem do wymienionych wartości.

Skłonność do zaufania nie okazała się istotnie zróżnicowana w przekroju regionów historycznych. Wyraźniejsze różnice stwierdzono w tym, komu się ufa. Wyraźnie niższe zaufanie do rodziny i sąsiadów odnotowano w regionie Zachodnim (ryc. 4). Wskazuje to na niższy poziom kapitału wiążącego. Również w tym regionie zadeklarowano niższe zaufanie do instytucji lokalnych, choć ta różnica nie była tak znaczna jak w poprzednim przypadku. Nie stwierdzono natomiast różnic w poziomie zaufania do instytucji ponadlokalnych, co pozwala wysunąć przypuszczenie o braku historycznie ukształtowanych zróżnicowań kapitału pomostowego.

Również w zakresie identyfikacji i tożsamości zaobserwowano odmienność regionu Zachodniego. Zdecydowanie mniejszy był tam odsetek respondentów jednoznacznie zadowolonych z miejsca zamieszkania (ryc. 5). Być może jest to paradoksalny efekt nieco większej mobilizacji obywatelskiej, na co może wskazywać relatywnie mały odsetek odpowiedzi wskazujących na niewielki wpływ lub brak wpływu i zaangażowania w sprawy okolicy. Nie bez znaczenia może też być większy krytycyzm wobec lokalnych elit, na co wskazuje mniejszy poziom zaufania, jakim darzą je mieszkańcy opisywanego regionu.

W kwestii oczekiwań wobec satysfakcjonującej pracy nie odnotowano wyraźnych różnic pomiędzy regionami historycznymi. To zapewne następstwo dużej dynamiki zmian na rynku pracy, które przynajmniej częściowo zmniejszają oddziaływanie uwarunkowań o charakterze długiego trwania. Niemniej należy podkreślić, że w tym przypadku nieco odmienne oceny ponownie formułowali respondenci z regionu Zachodniego. Znaczenie wszystkich warunków pracy były bardziej wyważone. Wyraźnie niższy był odsetek odpowiedzi podkreślających wagę danego czynnika, nieco częściej formułowano za to odpowiedzi neutralne lub negatywne. 
W świetle badanych cech uwidocznił się ograniczony zakres i skala zróżnicowań w przekroju regionów historycznych. Większe różnice dotyczyły postaw kształtujących kapitał społeczny, co jest następstwem długotrwałego charakteru procesów, który go kształtują, Obszarem, który cechuje się najwyraźniejszą jego odmiennością okazał się region Zachodni.

1

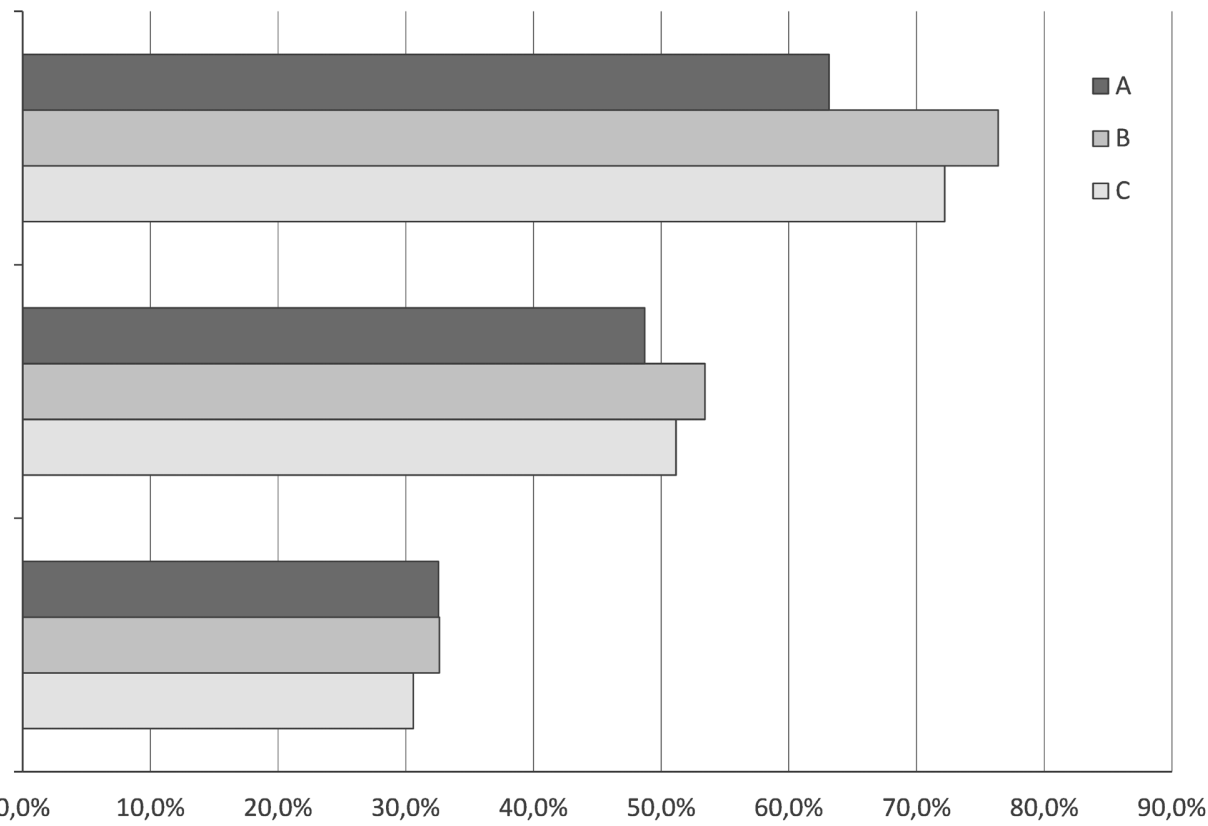

Ryc. 4. Zaufanie do ludzi i instytucji (\% odpowiedzi twierdzących) w opinii mieszkańców wsi województwa pomorskiego w 2013 r.

Regiony: A - Zachodni, B - Środkowy, C - Wschodni; ludzie i instytucje: 1 - rodzina i sąsiedzi, 2 - instytucje lokalne (sołtys, księża w parafii, wójt, radni rady gminy, straż pożarna, straż gminna, lekarze, policja, sądy), 3 - instytucje ponadlokalne (organy władz państwa i wybranych instytucji centralnych np. ZUS-u, NBP, GPW w Warszawie).

Źródło: opracowanie własne na podstawie wyników badania ankietowego.

Trust in the people and institutions (\% of positive answers) according to the inhabitants of rural areas in Pomorskie Province in 2013

Regions: A - Western, B - Central, C - Eastern; People and institutions: 1 - Family and neighbours, 2 - Local institutions (village headman, parish priests, commune head, members of the commune council, fire brigade, commune police, doctors, police, courts), 3-Supra-local institutions (state government authorities and selected central institutions, e.g. ZUS, NBP and Warsaw Stock Exchange).

Source: autor's own study based on questionnaire survey results. 


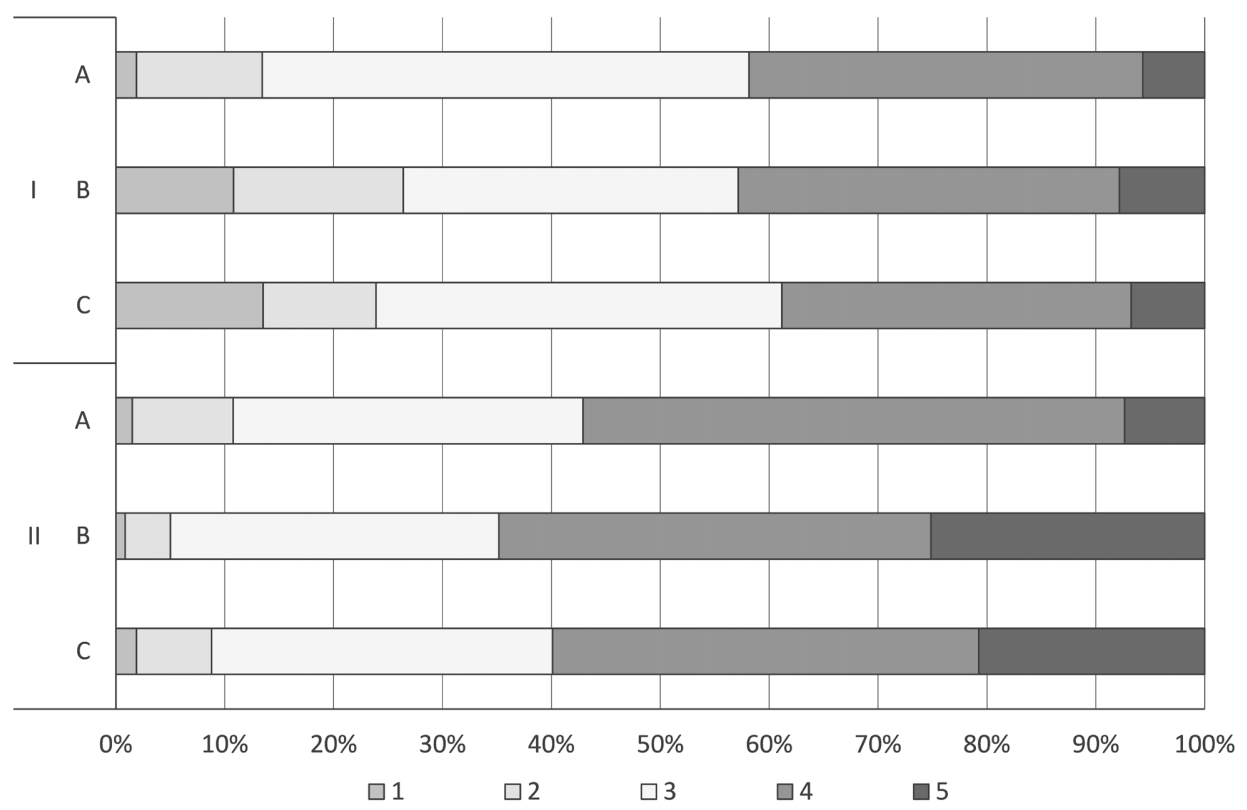

Ryc. 5. Zaangażowanie w sprawy lokalne i zadowolenie z miejsca zamieszkania w opinii mieszkańców wsi województwa pomorskiego w 2013 r.

Pytania: I - zaangażowanie w sprawy lokalne, II - zadowolenie z miejsca zamieszkania; regiony: A - Zachodni, B - Środkowy, C - Wschodni; odpowiedzi: 1 - nie, 2 - raczej nie, 3 -trudno powiedzieć, 4 - raczej tak, 5 - tak. Źródło: opracowanie własne na podstawie wyników badania ankietowego.

Involvement in local affairs and satisfaction with place of residence according to the inhabitants of of rural areas in Pomorskie Province in 2013

Questions: I - Involvement in local affairs, II - Satisfaction with place of residence; regions: A - Western,

B-Central, C-Eastern; answers: 1 -No, 2 -Rather not, 3 -Difficult to say, 4 -Rather yes, 5 - Yes.

Source: author's own study based on questionnaire survey results.

\section{Podsumowanie}

Analiza opinii mieszkańców województwa pomorskiego na temat systemu wartości i postaw istotnych dla wykształcenia kompetencji warunkujących poziom kapitału ludzkiego i społecznego pozwoliła na sformułowanie trzech wniosków dotyczących terytorialnego zróżnicowania badanych cech.

Po pierwsze, zróżnicowanie w układzie miasto-wieś wartości i postaw uznanych za ważne w kształtowaniu kompetencji, które są składowymi kapitału ludzkiego lub społecznego (zadowolenie z życia, zaufanie, identyfikacja z miejscem zamieszkania, postawy wobec pracy) okazało się mniejsze niż należałoby się spodziewać, biorąc pod uwagę dane o poziomie przedsiębiorczości i aktywności społecznej. Jeżeli przyjąć, że wyniki badania ankietowego pozwalają na analizę niektórych elementarnych składowych obu kapitałów, a dwa przywołane powyżej wskaźniki obrazują ich końcową wartość, to widać, że różnice w układzie miasto-wieś w ograniczonym stopniu wynikają z systemu wartości i postaw mieszkańców. Przewagę miast nad terenami wiejskimi w obu aspektach kształtują w większym stopniu inne czynniki - przede wszystkim korzyści aglomeracji, które można zdyskontować w działalności gospodarczej, i do pewnego stopnia, społecznej. Ważną rolę 
pełni też stopień centralności danego ośrodka, wyrażający się zasięgiem obsługi obszarów sąsiednich. Wysoki poziom przedsiębiorczości z reguły nie jest jedynie następstwem posiadanych kompetencji, ale także wielkości rynku zbytu, obecności kooperantów i wyposażenia w odpowiednią infrastrukturę techniczną. Wysoki poziom aktywności społecznej mierzony liczbą instytucji nie bierze pod uwagę faktu, że duża część z nich działa ponadlokalnie. Brak siedziby takiej instytucji na określonym terytorium nie oznacza więc, że jego mieszkańcy nie są aktywnymi członkami. Nie oznacza to, że wartości i postawy ludzkie nie mają wpływu na poziom i charakter kapitału ludzkiego i społecznego. Są one niezbędne, aby w ogóle posługiwać się pojęciem kapitału w odniesieniu do ludzkich populacji. W istniejących ramach ustrojowych nie wystarczają jednak do zapobieżenia narastaniu dysproporcji rozwojowych w układzie miasto-wieś. Jednocześnie należy mieć na względzie, że wyniki badań ankietowych nie powinny być interpretowane wprost. Wyraźnie mniejsze różnice w kwestiach istotnych dla kształtowania kapitału społecznego i ludzkiego po części wynikają z formułowania ich w określonym kontekście społecznym. Ramy odniesienia tworzą nie abstrakcyjne wskaźniki, a raczej sytuacja ludzi w bliższych i dalszych kręgach otoczenia. Prowadzi to do spłaszczenia spektrum formułowanych ocen. Subiektywizm opinii i opartych na nich wyników badań ankietowych nie umniejsza ich wiarygodności i przydatności w identyfikacji zasobów rozwojowych. Są one podstawą podejmowania wielu codziennych decyzji, które skutkują działaniami wzmacniającymi lub prowadzącymi do erozji kapitału społecznego i ludzkiego. W przypadku dostępności danych z obu rodzajów źródeł należy je konfrontować, co powala lepiej zrozumieć przyczyny terytorialnego zróżnicowania obu kapitałów.

Po drugie, wpływ podmiejskiego położenia na terytorialne zróżnicowanie badanych zmiennych potwierdzony został głównie w zakresie wprost wynikającym z oddziaływania korzyści aglomeracji. Większe różnice dotyczyły jedynie zadowolenia z miejsca zamieszkania, a także niektórych postaw wobec pracy. Bliskość miasta zapewnia większy dostęp do usług komercyjnych i publicznych. Obszary podmiejskie funkcjonują jako część większego rynku pracy, który niemal zawsze oferuje lepsze warunki zatrudnienia niż rynek peryferyjny. To w istotnym stopniu kształtuje postawy i aspiracje zawodowe. Żywiołowa i chaotyczna urbanizacja potencjalnie powinna negatywnie oddziaływać na niektóre aspekty kapitału społecznego w następstwie konfliktów społecznych, które stwarza (Wójcik i in. 2014). Wydaje się, że zagadnienie to wymaga dalszych badań. Być może konflikty te są mobilizujące i wzmacniają kapitał wiążący zantagonizowane grupy.

Po trzecie, wpływ czynników długiego trwania na zróżnicowanie badanych cech został potwierdzony w ograniczonym zakresie. W przekroju regionów historycznych zauważono pewne odmienności w odpowiedziach formułowanych przez respondentów z zachodniej części województwa. Wydaje się jednak, że w znacznej mierze tłumaczyć je można kryzysem transformacyjnym, który w rezultacie upadku państwowych gospodarstw rolnych spowodował trwałą zapaść społeczno-gospodarczą najbardziej peryferyjnych części tego regionu. Peryferyjność, w rozumieniu dostępności transportowej, może być czynnikiem decydującym, gdyż w silniej zurbanizowanym, korzystniej położonym regionie Wschodnim, również dotkniętym upadkiem państwowych gospodarstw rolnych, nie formułowano opinii wyraźnie odmiennych.

Wielość przedstawionych interpretacji towarzyszących analizie terytorialnego zróżnicowania kapitału społecznego i ludzkiego wynika z jednej strony ze złożoności warunków i czynników kształtujących oba kapitały, z drugiej zaś z nieprecyzyjności samych pojęć, a na- 
wet ich wtórności, na co wskazują krytycy koncepcji. Wydaje się jednak, że obie koncepcje kapitału dość dobrze przystają do rzeczywistości społecznej, w której silna konkurencja, także pomiędzy jednostkami terytorialnymi, postrzegana jest jako główny mechanizm rozwoju. Może być ona również pomocna w identyfikacji zasobów lokalnych dla rozwoju wsi, która pozbawiona przewagi w postaci zakumulowanego kapitału materialnego, większym stopniu powinna dbać o wzmocnienie kapitału społecznego i ludzkiego.

\section{Literatura}

Bański J., 2008, Wiejskie obszary sukcesu gospodarczego, Studia Obszarów Wiejskich, 14.

Bański J., 2010, Odrębność obszaru podmiejskiego w kontinuum miejsko-wiejskim, Czasopismo Geograficzne, 80, 4, s. 210-228.

Bański J., 2014, Współczesne typologie obszarów wiejskich w Polsce - przeglaqd podejść metodologicznych, Przegląd Geograficzny, 86, 4, s. 441-470.

Becattini G., Bellandi M., Ottati G., Sforzi F., 2003, From industrial districts to local development, Edward Elgar Publishing, Cheltenham.

Bird B., 1995, Towards a theory of entrepreneurial competency, [w:] J.A. Katz, R.H. Brockhaus (red.), Advances in entrepreneurship, firm emergence and growth, JAI Press, s. 51-72.

Brol R., 1998, Rozwój lokalny - nowa logika rozwoju gospodarczego, Prace Naukowe Akademii Ekonomicznej we Wrocławiu, 785, s. 11-15.

Coffey W.J., Polese M., 1984, The concept of local development: a stages model of endogenous regional growth, Papers in Regional Science, 55, 1, s. 1-12.

Coffey W.J., Polese M., 1985, Local development: conceptual bases and policy implications, Regional Studies, 19, 2, s. 85-93.

Coleman J. S., 1998, Social Capital in the Creation of Human Capital, American Journal of Sociology, 94, s. 95-120.

Czapiewski K.t., 2006, Rural areas of success - in the search definitions and measures, Europa XXI, 15, s. 77-86.

Czapiewski K.t., 2010, Koncepcja wiejskich obszarów sukcesu społeczno-gospodarczego i ich rozpoznanie w województwie mazowieckim, Studia Obszarów Wiejskich, 22, s. 7-218.

Czyżewski A.B., Góralczyk-Modzelewska M., Saganowska E., Wojciechowska M., 2001, Regionalne zróżnicowanie kapitału ludzkiego w Polsce, Studia i Prace. Z Prac Zakładu Badań Statystyczno-Ekonomicznych GUS i PAN, 277, s. 1-27.

Domański B., 2004, Krytyka pojęcia rozwoju a studia regionalne, Studia Regionalne i Lokalne, 16, 2, s. 7-23.

Działek J., 2011a, Kapitał społeczny jako czynnik rozwoju gospodarczego w skali regionalnej i lokalnej, Wydawnictwo Uniwersytetu Jagiellońskiego, Kraków.

Działek J., 2011b, Kapitał społeczny - ujęcia teoretyczne i praktyka badawcza, Studia Regionalne i Lokalne, 45, 3, s. 100-118.

Fedyszak-Radziejowska B., 2005, Czy kapitał społeczny bez społecznego zaufania jest możliwy? Przykłady polskich gmin wiejskich, [w:] T. Kaźmierczak, M. Rymsza (red.), Kapitał społeczny. Ekonomia społeczna, Instytut Spraw Publicznych, Warszawa, s. 65-90.

Fedyszak-Radziejowska B., 2014, Społeczności wiejskie dziesięć lat po akcesji. Postawy, wartości i uwarunkowania społeczno-ekonomiczne, [w:] I. Nurzyńska, W. Poczta, Polska wieś 2014. Raport o stanie wsi, Wydawnictwo Naukowe Scholar, Warszawa, s. 153-174. 
Frykowski M., Starosta P, 2005, Kapitał społeczny na terenie województwa łódzkiego, [w:] K. Gorlach, G. Foryś (red.), W obliczu zmiany. Wybrane strategie działania mieszkańców polskiej wsi, Wydawnictwo Uniwersytetu Jagiellońskiego, Kraków, s. 79-106.

Gorzelak G., 2003, Bieda i zamożność regionów. Założenia, hipotezy, przykłady, Studia Regionalne i Lokalne, 11, 1, s. 37-59.

Grosse G. T., 2002, Przeglad koncepcji teoretycznych rozwoju regionalnego, Studia Regionalne i Lokalne, 8, 1, s. 25-48.

Halamska M., 2008, Kapitał społeczny wsi. Próba rekonstrukcji, Przegląd Socjologiczny, 57, s. 81-105.

Heffner K., 2007, Wiejskie rynki pracy - kurczqce się zasoby czy niewyczerpane rezerwy?, [W:] W. Kamińska i K. Heffner, Wiejskie rynki pracy - zasoby, aktywizacja, nowe struktury, Studia KPZK PAN, 145 , s. 8-51.

Herbst M., 2007, Wpływ kapitału ludzkiego i społecznego na (krótkookresowy) wzrost gospodarczy w polskich podregionach, [w:] M. Herbst (red.), Kapitał ludzki i kapitał społeczny a rozwój regionalny, Wydawnictwo Naukowe Scholar, Warszawa, s. 166-203.

Janc K., 2009, Zróżnicowanie przestrzenne kapitału ludzkiego i społecznego w Polsce, Rozprawy Naukowe Instytutu Geografii i Rozwoju Regionalnego Uniwersytetu Wrocławskiego, 8, s. 1-120.

Jażdżewska I., Frykowski M., 2006, Rozwój gospodarczy gmin a aktywność obywatelska mieszkańców wsi i małych miast województwa łódzkiego, [w:] E. Psyk-Piotrowska (red.), Kapitał społeczny, partycypacja obywatelska, rozwój lokalny, Wydawnictwo Uniwersytetu Łódzkiego, Łódź, s. $104-128$.

Kowalewski A., Mordasewicz J., Osiatyński J., Regulski J., Stępień J., Śleszyński P., 2014, Ekonomiczne straty i społeczne koszty niekontrolowanej urbanizacji $w$ Polsce - wybrane fragmenty raportu, Samorząd Terytorialny, 25, 4, s. 5-21.

Krzysztofek K., Szczepański M.S., 2005, Zrozumieć rozwój. Od społeczeństw tradycyjnych do informacyjnych, Wydawnictwo Uniwersytetu Śląskiego, Katowice.

Knieć W., Goszczyński W., Obracht-Prondzyński C., 2013, Kapitał społeczny wsi pomorskiej, Kaszubski Uniwersytet Ludowy, Wieżyca.

Łabędzki H., 2011, Kapitał ludzki i społeczny na obszarach wiejskich powiatu Żary, Stowarzyszenie Ekonomistów Rolnictwa i Agrobiznesu. Roczniki Naukowe, 13, 2, s. 284-289.

Marchewka K., 2000, Główne nurty w teorii kapitału, Ruch Prawniczy, Ekonomiczny i Socjologiczny, 63, 3, s. 105-120.

Mularska M., 2006, Aprobata wybranych norm społecznych na obszarach wiejskich, [w:] E. PsykPiotrowska (red.), Kapitał społeczny, partycypacja obywatelska, rozwój lokalny, Wydawnictwo Uniwersytetu Łódzkiego, Łódź, s. 89-103.

OECD, 1998, Human Capital Investment. An International Comparison, Paris.

Parysek J.J., 1997, Podstawy gospodarki lokalnej, Wydawnictwo Naukowe UAM, Poznań.

Piróg D., 2015, Kompetencje z zakresu przedsiębiorczości: rozważania teoretyczne i ich ilustracje w obszarze szkolnictwa wyższego, Przedsiębiorczość - Edukacja, 11, s. 364-376.

Porter M.E., 2000, Porter o konkurencji, PWE, Warszawa.

Psyk-Piotrowska E., Zajda K., Kretek-Kamińska A., Walczak-Duraj D., 2013, Struktura i uwarunkowania kapitału społecznego w lokalnych grupach działania, Wydawnictwo Uniwersytetu Łódzkiego, Łódź.

Ptak A., 2015, Lokalna społeczność w procesie tworzenia funduszu sołeckiego, Studia Regionalne i Lokalne, 59, 1, s. 138-153.

Raport techniczny z realizacji badania "Wzorcowy System Regionalny Monitoringu Jakości Usług Publicznych i Jakości Życia”, 2013, Pracownia Badań Społecznych (maszynopis). 
Sagan I., 2007, Teorie rozwoju regionalnego i ich praktyczne zastosowanie, [w:] G. Gorzelak, A. Tucholska (red.), Rozwój, region, przestrzeń, Ministerstwo Rozwoju Regionalnego, Warszawa, s. 91-108.

Walukiewicz S., 2007, Four Forms of Capital and Proximity, Working Paper of Systems Research Institute of Polish Academy of Sciences, 3, s. 1-40.

Wendt J., 2007, Wymiar przestrzenny struktur i aktywności społeczeństwa obywatelskiego w Polsce, Prace Geograficzne, 208, s. 7-230.

Wójcik M., 2010, Wieś metropolitalna-podstawowe pojęcia i koncepcje badawcze, 58. Zjazd Polskiego Towarzystwa Geograficznego, Łódź, 8-12 września 2010 r.

Wójcik M., 2013, Geografia wsi w Polsce. Ewolucja koncepcji i problemów badawczych, Acta Universitatis Lodziensis, Folia Geographica Socio-Oeconomica, 13, s. 4-18.

Wójcik M., Dmochowska-Dudek K., Traczyk A., 2014, Konflikty społeczno-przestrzenne na obszarach wiejskich województwa łódzkiego, Biuletyn Krajowej Sieci Obszarów Wiejskich Województwa Łódzkiego, 4, s. 8-11.

Zaucha J., Brodzicki T., Ciołek D., Komornicki T., Mogiła Z., Szlachta J., Zaleski J., 2015, Terytorialny wymiar wzrostu i rozwoju, Difin SA, Warszawa.

\section{Summary}

The article is to complement data on territorially diversified social and human capital in rural areas. The study concentrated on rural areas of Pomorskie Province, broken down by suburban and other rural communes, and broken down by historical regions. The subject of the study is human and social capital. The term 'human capital' is understood as a collection of knowledge, skills and competencies of given persons, used for the purpose of economic activity. Social capital, on the other hand, is the ability of cooperative interrelations between people in a group or organisation to achieve common benefits. Both types of capital are significant, intangible resources necessary for the local development. The article focuses on selected aspects of both types of capital which are neglected in most studies relying on secondary data, due to measurement difficulties. Therefore, primary data was used from polls conducted on a group of 7,100 individuals (including 2,300 rural residents). The analysis covered the following issues: the value of life, trusting people and institutions, identification and relation with the work place, attitude towards work. The results consisted in three categories of conclusions. Firstly, as indicated by the most common indicators of social activity and entrepreneurship, the analysed characteristics do not differ between the city inhabitants and those in rural areas. Data on entrepreneurship and social activeness are easily accessible at every level of spatial integration and are commonly applied. Nevertheless, they should be interpreted with greater caution as the value of these indicators results directly from defined features of particular individuals and their community constituting human and social capital. The individuals' and communities' environment has a considerable impact on their functioning in society. On the other hand, polls indicate that they also cannot be interpreted directly. Smaller differences in issues meaningful for the development of social and human capital result partially from the way in which they are formulated in the social context. The reference framework is rather the situation of people in the closer and further environment than abstract indicators. This leads to flattening the spectrum of formulated assessments. Secondly, a lower 
level of studied features was generally not observed in rural suburbs with the exception of its components which are directly dependent on the agglomeration economies. Thirdly, in terms of historical regions, responses formulated by the respondents of the western part of the Province showed certain distinctive features. However, it seems that this might be attributed to the transition crises rather than long-term conditions. 